\title{
Nationalism, "Philosemitism," and Symbolic Boundary-Making in Contemporary Poland
}

\author{
GENEVIÈVE ZUBRZYCKI \\ Sociology, University of Michigan
}

\begin{abstract}
With one religion, we cannot listen
With one color, we cannot see

With one culture, we cannot feel

Without you, we cannot even remember

Without you, we remain locked away in the past

With you, a future will open before us.
\end{abstract}

${ }_{\text {Nightmares }}{ }^{1}$

\section{IN T R O D U C T I O N}

There is little left of Poland's once large, vibrant, and diverse Jewish communities, which prior to World War II represented approximately 10 percent of its

Acknowledgments: Research for this article was generously funded by grants from the University of Michigan's Office of Research, the Rackham Graduate School and LSA, and the Society for the Scientific Study of Religion. A research fellowship at the UM's Humanities Institute allowed me to complete the research and start writing. I am grateful to Natalie Smolenski, Jessica Zychowicz and Anna Woźny for their research assistance at various stages of the project. Previous versions of the article were presented in several venues and my argument greatly benefited from the questions and comments I received at the University of Toronto, the University of Georgia, Notre Dame, the University of Chicago, Princeton, Rutgers, Northwestern, the Université de Montréal, the École des Hautes Études en Sciences Sociales in Paris, the University of Warsaw, and the European University Institute in Florence. Thanks also to Doris Bergen, Jon Fox, Zvi Gitelman, Jan Grabowski, Ruth Ellen Gruber, Irena Grudzińska-Gross, Rob Jansen, Paul C. Johnson, Erica Lehrer, Marcin Napiórkowski, Aga Pasieka, Bożena Shallcross, David Smilde, Iddo Tavory, Karen Underhill, Jeff Veidlinger, Piotr Wróbel, Natalie Zemon-Davis, Yael and Eviatar Zerubavel, as well as the members of the Terrorscape Research Group and the anonymous reviewers of $\mathrm{CSSH}$ for their constructive criticism and helpful suggestions. My biggest debt, and most heartfelt thanks, are for Jonathan Ornstein who opened the doors of Kraków's JCC to me in 2010 and welcomed me on my multiple visits since then. It is at, and through the JCC, that I met many volunteers who generously agreed to share with me their motivations for participating in Jewish life and their visions of Polish society more broadly. I am grateful also to Janusz Makuch for many conversations and to his team for giving me a behind-the-scene look at the Festival.

1 All translations in the text are mine unless otherwise noted. Those words are spoken by Sławomir Sierakowski in a speech he addresses to Jews in Yael Bartana's film Nightmares (2007). They later became part of The Jewish Renaissance Movement in Poland's Manifesto. I discuss the film and the movement below. 
population. While Poland then had the largest Jewish population in Europe (about 3.5 million), only between seven thousand and forty thousand Jews live in that country now, numbers varying depending on sources, the criteria used to determine Jewishness, and the year the data was collected. ${ }^{2}$ Yet there are currently nearly forty festivals of Jewish culture held in almost as many Polish cities and towns, most of them initiated in the 1990s and 2000s. The dramatic growth in size and popularity of Kraków's Festival of Jewish Culture is telling: founded in 1988 as a modest, two-day local affair consisting primarily of films and lectures with limited public appeal, it is now a major national and international festival; under the patronage of the president of the Republic of Poland it lasts eleven days and is attended by some thirty thousand people from Poland and abroad (Kraków Festival of Jewish Culture [FKŻK] Annual Reports 1991-2013). Its final open-air concert, "Shalom on Szeroka Street," is free to the public and televised nationwide. The festival's popularity is indexical of non-Jewish Poles' growing interest in Jews and all things Jewish in Poland, but that interest is observable all year long, in the commercial success of klezmer music (Waligórska 2013), the proliferation of Judaica bookstores and Jewish-style restaurants, the opening of new museums, memorials, and memory spaces, ${ }^{3}$ a growing engagement of artists and public intellectuals with Poland's Jewish past and Polish-Jewish relations more broadly, and the emergence of Jewish studies programs at multiple universities (Wodziński 2011). The last indicator of this cultural phenomenon, about which there are no official statistics, is a modest but rising number of conversions to Judaism. These converts are often people who discover Jewish roots and feel compelled to "return to the source" (Reszke 2013), but sometimes they are Poles without Jewish ancestry who are nevertheless called or seduced by the appeal of Judaism (personal interviews with Rabbis Schudrich, Pash, Her-

2 In 1989, the American Jewish Year Book estimated the total Jewish population of Poland to be five thousand, of which nearly two thousand were registered with Jewish communities. By the beginning of the new millennium, the number of Polish Jews registered with communities, belonging to Jewish organizations, or receiving aid from the American Jewish Joint Distribution Committee had nearly quadrupled to between seven and eight thousand. As many as forty thousand Polish citizens are now thought to have some Jewish ancestry (American Jewish Year Book 2002; 2003). When asked how many Jews currently live in Poland, Chief Rabbi of Poland Michael Schudrich often responds: "How many do you think there are? Take that number and double it. And now add 1. There's always one more coming out of the closet" (informal conversation, Warsaw, 22 Mar. 2013).

3 Kraków's Galicja Jewish Museum was founded in 2003; Schindler's Factory Museum on the occupation in World War II Kraków opened in 2010; the Museum of Kraków's Ghetto The Eagle Pharmacy opened in 2013; and the Museum of the History of Polish Jews in Warsaw opened its building in April 2013 and its main exhibit in October 2014. There are many other smaller museums and educational centers throughout Poland, such as the Świętokrzyski shtetl in Chmielnik, which opened in 2014. 
berger, Horovitz, and Segal in 2012 and 2013; personal interviews with converts, Mar. 2011, Mar. 2013). ${ }^{4}$

To be sure, these different processes are facilitated by the specific historic juncture brought about by the fall of communism. While the Shoah qua Shoah was rarely discussed under communism and one's Jewishness was seldom publicly embraced, after 1989 it became possible to examine the past. Many Poles discovered Jewish origins and those who already knew could openly talk about them. ${ }^{5}$ The opening of the Eastern Bloc made foreign institutional support and funding for the renewal of Jewish communal life available and the development of heritage and Holocaust tourism facilitated the gentrification of formerly neglected Jewish neighborhoods and sites (Kugelmass and OrlaBukowska 1998; Jochnowitz 1998; Murzyn 2006; Gruber 2002; Lehrer 2013). ${ }^{6}$ This is especially true for Kraków, which is only an hour away from Auschwitz and which has greatly benefited, and profits, from the post-Schindler's List tourism boom. These parallel processes brought non-Jewish Poles in contact with a different narrative of World War II than the one they had been socialized in during communism, namely that Poles were the main victims of the war. In 2000, with historian Jan Gross' publication of Neighbors, a short book that recounts in painful details how ethnic Poles tormented and murdered their Jewish neighbors in the small town of Jedwabne in July 1941, they experienced another shockwave by discovering their own role in the Holocaust. This led to significant soulsearching and a process of national demystification that is still on-going (Gross 2000; Gross and Grudzińska-Gross 2011; Machcewicz and Persak 2002; Polonsky 2009; Forecki 2010; Grabowski 2013; Zubrzycki 2006; 2013).

\section{National Identity's Symbolic Boundaries}

While this complex set of historical, political, economic, and cultural forces was crucial to the twin rebirth of Jewish communal life and non-Jewish

\footnotetext{
4 While I name public figures I formally interviewed, I have changed the names of interviewees who were not representing institutions in order to preserve their anonymity.

5 See, for example, Agata Tuszyńska's literary autobiographical account (2005), which opens with the following line: "This book has been within me for years, like a secret, ever since I found out that I'm not who I thought I was-from the moment my mother decided to tell me she was Jewish." The author was born after the war and her mother had survived the Warsaw Ghetto. She learned about her mother's life story only as a teenager. That sentence is powerful because of the weight of transgenerational secrets, but also because the revelation of the author's "true" identity was consciously made by her mother, who decided - that is, considered whether or not, at that point in their lives - to tell her daughter that she/they were Jewish. Jewishness, although considered a "fact" ("ever since I found out that I'm not who I thought I was") is not an obvious one-it must be reflected upon before deciding to share that "fact" with even those to whom one is closest. Other authors and public intellectuals, such as Bożena Keff and Piotr Paziński, have discussed similar experiences. For narratives of "third-generationers" "discoveries," see Reszke 2013.

6 For accounts of Jewish community revivals by their main participants, see Krajewski 2005; Gebert 2008; Penn, Gebert, and Goldstein 2009; and Dodziuk 2010.
} 
Poles' interest in all things Jewish, in this article I concentrate on the latter aspect of what is indiscriminately called the "Jewish Revival." I do not claim, of course, that the "revival" has been the work of non-Jewish Poles alone: Polish Jews are obviously key actors in the revitalization of different forms of Judaism and the solidification and expansion of Jewish communal life. Non-Polish Jews also play an important role in that process, through various forms of philanthropic and missionary work. ${ }^{7}$ My focus here, however, is primarily on non-Jewish Poles' rediscovery of Poland's Jewish past and discovery of multiple facets of Jewish history and contemporary culture. This focus is justified by two motivations: empirically, non-Jewish Poles' interest in things Jewish is more puzzling than Jews' interest, and theoretically, it helps us get closer to the main sociological question that guides this essay, namely, whether and how symbolic boundaries can be redefined in an ethnically and denominationally homogeneous society.

I argue that non-Jewish Poles' "resurrection of the Jew" through memory work, social activism, and cultural practices cannot be reduced to the commodification of Jewish culture, nor does it merely mark the antisemitic folklorization of Jews and things Jewish-an aspect that Erica Lehrer has convincingly drawn out in her work $(2003$; 2013). Neither should it be read as solely Poles' outlet for the working through of cultural trauma or their collective expression and expiation of guilt. No doubt a bit of each of these fuels the multi-pronged phenomenon, but it is also part of a broader and long-standing effort by both Jewish and non-Jewish cultural elites, social activists, ordinary citizens, and some state agencies to soften, stretch, and reshape the symbolic boundaries of Polishness that the Right has sought to harden and shrink using a conservative, nationalist version of Catholicism as its primary tool. The "Jewish turn" is a means to symbolically reclaim the pluralistic society that was eradicated during World War II, the memory of which the socialist state materially erased and ideologically suppressed in its effort to legitimize and naturalize the new borders and new demographic makeup of the postwar nation-state. ${ }^{8}$

\footnotetext{
7 The overwhelming majority of Rabbis in Poland are not Polish-born, Chabad has a significant presence in several cities, and Shavei Israel is actively involved in finding the "Hidden Jews of Poland." Western philanthropic organizations such as The Joint Distribution Committee and the Taube and Lauder Foundations also play a significant role in the revitalization of Jewish life in Poland.

${ }^{8}$ By "material erasure" I mean the building over Jewish ruins or the repurposing of Jewish buildings such as the conversion of synagogues into swimming pools, libraries, or cinemas, yeshivas into cultural centers. On the neighborhood built over the ruins of the Warsaw ghetto, see Janicka 2011; and Chomątowska 2012. On the treatment of Jewish ruins more broadly in Poland and Germany, see Meng 2012. For a novel based on ghost stories, see Ostachowicz's The Night of the Living Jews (2012). On Polish memory/amnesia of Jews, see Irwin-Zarecka 1989; Gitelman 2003; Steinlauf 1997; and Zubrzycki 2006; 2013.
} 
Polish "philosemitism"" is partly an attempt to build and promote a plural society in (and against) an ethnically and religiously homogenous nation-state. This is an argument I and others have made elsewhere (e.g., Zubrzycki 2010; 2013; Meng 2012; Lehrer 2013). Although the diversity that characterized Poland for most of its history is unlikely to return, civic and cosmopolitan nationalists see the recognition of that legacy as a tool not only to build an open society, but also to mark Poland as a polity that meets the standards of an internationally normative model of nationhood that values and encourages pluralism and multiculturalism. ${ }^{10}$

I thus have two principal objectives in this article: the first is empirical - to make sense of non-Jewish Poles' interest in all things Jewish without reproducing a simplistic dichotomy between anti- and philosemitism; the second is theoretical - to show the role of cultural forms and practices in shaping the contours of national identity. Poland is an auspicious place to study these questions because over 95 percent of its population is ethnically Polish and nominally Catholic. Over 93 percent of Polish citizens declare a belief in God (Centrum Badania Opinii Społecznej [CBOS] 2013), and 70 percent participate in religious services at least once a month (CBOS 2009; 2013). Such a demographic context and religious landscape are unusual, and revealing for the study of the inner workings of symbolic boundary-making and the role played by cultural work in that process.

The rich and varied literature on symbolic boundaries in the social sciences is beyond the scope of this article to review. I shall merely stress here that most

\footnotetext{
9 The term "philosemitism" was coined by self-avowed antisemites in Germany in the 1880s to denigrate their opponents (Karp and Sutcliff 2011: 1). The original signification of the word was political and clearly derogatory. It also denotes the problematic objectification of Jews as a group, which the phenomenon shares with antisemitism. While I recognize the genealogy of the term and the various connotations it may have for Jews and non-Jews, I adopt it here sociologically to denote a wide spectrum of practices motivated by a curiosity and desire to learn about Jewishness, and attempts to uncover and preserve the remnants of Jewish life and honor the millions of Jews (Polish and non-Polish) murdered on Polish soil. For a discussion of the history and theoretical underpinnings of the terms antisemitism, anti-antisemitism, philosemitism, and allosemitism, see Bauman 1998; Altefix 2000; and Judaken 2008. For empirical studies, see Stern 1991; Mushkat 1992; and Karp and Sutcliff 2011. On antisemitism in Poland, see Krzemiński 1996; 2009; and Bilewicz, Winiewski, and Radzik 2012. On antisemitism and opposition to it, see Blobaum 2005. On representations of Jews in Poland, see the now-classical study by Cała 1995; and the works of Michlic 2006; Tokarska-Bakir 2008; and Lehrer 2013.

${ }_{10}$ Michael Meng (2012: 10) refers to this process as "redemptive cosmopolitanism," which he defines as the "commemorative display of multiethnicity that celebrates the cathartic, redemptive transformation of Germans and Poles into tolerant democratic citizens." He sees the recent metamorphosis of formerly Jewish spaces "into signifiers of redemptive cosmopolitanism, a performative embrace of the Jewish past that celebrates the liberal, democratic nation-state rather than thinking critically about its past and present failures" (p. 250). While I agree with Meng that at the center of the revival is a desire to redefine the national self around cosmopolitanism, I disagree with his assessment that it replaces or prevents critical thinking about "the democratic state's past and present failures." I would argue that a critical engagement with the past lies at the core of social activists' involvement with and in the Jewish revival.
} 
of it concerns the creation, maintenance, and transgression of boundaries between groups. In studies of ethnicity and nationalism, the classic work is that of Frederick Barth, who opened that field of research half a century ago by showing that ethnic identity is a feature of social organization and not of "culture." By shifting the attention away from a substantive notion of difference and toward the social organization of difference, Barth was introducing the concept of boundaries between ethnic groups. This reframing proved a formidably fruitful lead that spanned several decades and crossed disciplines and empirical objects. Through their careful review of works in various disciplines and subfields, Lamont and Molnar (2002) identified four properties of boundaries based on ethnicity, class, gender, or race: permeability, salience, durability, and visibility, providing researchers additional analytical tools to analyze boundaries between various social groups. It was, however, the flipside of boundary-making that animated Brubaker et al. in their study of ethnicity in the Romanian city of Cluj (2006). Instead of taking for granted that ethnonationality does matter, they studied when, why, and how it did and did not. They were interested more specifically in the ways in which, and instances when, symbolic boundaries between ethnic groups became apparent and salient and how fluid and context-dependent those boundaries were.

Those contributions were crucial, yet that scholarship focuses on cases where difference, however arbitrarily defined, exists. The question therefore remains: how is boundary work done in a society where ethnonationality is the key collective marker of group identity and where the overwhelming majority of people belong to the same ethnonational group? Instead of focusing on properties of boundaries, or on how symbolic boundaries are created, maintained, or transgressed between ethnic and national groups, I will illuminate the process through which boundaries are redefined within one ethnonational community. I investigate the internal process through which individuals or social groups are considered to "truly" belong, or not, to the national community, and the symbolic violence involved in that process (Bourdieu 1991).

\section{Methods and Data}

To explain the contemporary enthusiasm for things Jewish and to see whether and how it is related to symbolic boundary (re)making, this study adopts macro, meso, and micro perspectives. I analyze Jewish-centered initiatives sponsored by state institutions, NGOs and bottom-up civic projects, and everyday individual practices (Fox and Miller-Idriss 2008). I have used archival and ethnographic methods to collect data that allow me to interpret different meanings that Jewishness has for the diverse actors and organizations engaged in the revival, both Jewish and non-Jewish, secular and religious.

The study builds on over forty months of fieldwork in Poland spanning the last two decades, during which I observed and documented changing PolishJewish relations and the rising interest of non-Jewish Poles in Jewish culture. 
Specifically for this project, I have conducted twenty-two weeks of fieldwork in Kraków and Warsaw since 2010: I was a participant observer in 2010 and 2014 at the Festival of Jewish Culture, which organizes a series of workshops, courses, and tours aimed at educating Jewish and non-Jewish Polish participants about Poland's Jewish past and present. I attended more than twenty workshops on topics as diverse as "Jewish cuisine," "Jewish dancing," "Jewish paper-cutting," "Hasidic singing," and "genealogy." I enrolled in daily Hebrew and Yiddish language classes offered through the festival, attended dozens of lectures, and embarked on multiple iterations of walking tours of "Jewish Kraków" to learn how Jewishness is presented and taught to nonJewish Poles who constitute the majority of those attending the events. While the festival is sometimes portrayed in the West as a kitsch "Disneyland," and Kazimierz as a Potemkin village in which Poles "play Indian," 11 these characterizations overlook the fact that the festival not only allows non-Jewish Poles to learn about Jewish culture, but that it also offers a safe, neutral, and non-intimidating space in which Poles who are rediscovering their Jewishness can acquaint themselves with some of its cultural forms. It also provides the occasion for Jews from across Poland to gather for symposia, book releases, and reunions, or to celebrate life-events. This annual event is therefore a significant space where Jewishness is performed at several levels and an important one for academic inquiry. My encounters and conversations during the festival with Polish and non-Polish participants (both Jewish and non-Jewish), Jewish community members and activists, tour guides, as well Jewish and non-Jewish volunteers provided me with significant insight into the varied meanings these practices have for ordinary, private citizens.

I have also attended numerous communal events in the Kraków and Warsaw Jewish communities, such as Sabbath dinners, anniversaries and other life event celebrations (weddings, bat mitzvahs), and religious holidays (Purim, Yom Kippur, Passover). My participation in mundane, everyday work at Kraków's Jewish Community Center (JCC), which opened in 2008, was also significant, as was my attendance at special events for Catholics and Protestants who were eager to learn about Judaism and Jewish culture, such as Christian Passover Seders.

\footnotetext{
${ }^{11}$ See, for example, the New York Review of Books blog of Shelley Salamansky, "Disney Diasporas" <http://www.nybooks.com/blogs/nyrblog/2011/dec/23/diaspora-disneys/>; or the New York Times travel report on Jewish communities in the world, in which the author praises Kraków's revival of Jewish culture while still remarking that the old Jewish Quarter "is a bit of a Disney world experience"; <http://www.nytimes.com/2014/09/21/travel/exploring-the-worlds-jewishcommunities.html?_r=0>. The "Disney," "playing Indian," or even "blackface" metaphors are sometimes made by members of the audience when I present my work in North America. They reflect a mix of disbelief, skepticism, and discomfort at the cultural phenomenon, with a hint of outrage. I often discuss those reactions with members of Jewish communities in Poland when the topic arises, which gives me insights into how they themselves perceive non-Jews' embrace of Jewishness and Jewish culture, and how they understand reactions to it outside of Poland.
} 
Moreover, I conducted over sixty in-depth, open-ended interviews with key actors and representatives of institutions involved in major Jewishrelated initiatives and activities. Interviewees included rabbis, cultural entrepreneurs, communal leaders, museologists, artists, and public intellectuals, as well as participants in communal and cultural events. About half of my formal interviewees are non-Jewish volunteers at Jewish institutions, non-Jewish members of an Israeli dance group, Christian evangelicals observing Jewish holidays, and non-Jewish Poles who are in the process of converting to Judaism or who recently discovered they have some Jewish ancestry and are recovering a Jewish identity through an active schedule of classes and practices.

Finally, I have collected materials documenting the emergence and transformation of various Jewish-centered initiatives and state-sponsored institutions such as festivals, museums, and university programs; memorials and significant artistic creations and projects; and the openings of commercial enterprises such as restaurants, cafes, and bookshops, with special attention to the reactions to these in the press. This simultaneous attention to micro, meso, and macro aspects of the revival provides me with a view both from above (from the production-side of the revival of Jewish culture in Poland) and from "below" (from its consumption and re-creation by participants). Most importantly, this approach has allowed me to develop an interpretation of Jewishness's varied meanings that is firmly grounded in empirical data about lived reality: by getting close to the actors actually engaging in Jewish-centered practices, paying close attention to the local contexts in which those practices and projects arise, and seeing how they are interpreted and appropriated by ordinary people reacting to them, I can paint a more nuanced picture of the phenomenal interest in all things Jewish in contemporary Poland.

\section{SYMBOLIC BOUNDARIES IN A “MONOCULTURAL" SOCIETY}

One of the key questions that animates public debates in Poland and intrigues social scientists alike is what pluralism and secularism can mean in a "monocultural" society like Poland (see Waligórska 2008; Zubrzycki 2010). To understand the challenges this situation poses, we must first take into account the processes through which Poland's current demographic makeup was achieved and naturalized.

For most of its history, Poland was significantly diverse, populated by people belonging to different ethnic, linguistic, and religious communities. With the advent of World War II and the Holocaust, and with the postwar redrawing of Poland's borders, pogroms, state-sponsored ethnic cleansing, and antisemitic purges, this picture changed dramatically: while ethnic Poles on the eve of the war constituted approximately 65 percent of the Second Republic's population, by the late 1940s they accounted for about 95 percent of the People's Republic. The religious makeup of the population within the new borders changed in a similar manner (Table 1). 
TABLE 1.

Ethnic and Religious Composition in the Second Republic of Poland and the Popular Republic of Poland. Data Sources: Michowicz 1988; Tomaszewski 1993; and Casanova 1994.

\begin{tabular}{|c|c|c|}
\hline & 1931 & 1946 \\
\hline Ethnic Poles & $65 \%$ & $96 \%$ \\
\hline Jews & $10 \%$ & \\
\hline $\begin{array}{c}\text { Ukrainians, Lithuanians, } \\
\text { Belorusians, Germans, } \\
\text { Tatars and others }\end{array}$ & $25 \%$ & $4 \%$ \\
\hline
\end{tabular}

\begin{tabular}{|l|l|l|}
\hline Catholics & $65 \%$ & $95 \%$ \\
\hline
\end{tabular}

The current ethnic and religious "homogeneity" is therefore the byproduct of relatively recent, and very violent, historical events and political processes. Yet it was successfully naturalized in the postwar period by both the state and the Catholic Church. In other words, institutions built or boosted their legitimacy by emphasizing this new ethnonational and denominational homogeneity and suppressing even the memory of diversity. Combined, these processes further tightened the association between Polishness and Catholicism (Zubrzycki 2006: 60-76; Porter-Szücs 2012).

If ideological pluralism was a "politically sensitive" issue under state socialism, systemic transformations after 1989 have not made it less so. In post-socialist and then post-EU Poland, the mere idea of pluralism has been vigorously contested. Intellectuals and politicians on the left and the center, as well as liberal Catholics, typically stress the nation's ideological heterogeneity and argue that in a plural society religion (and Catholicism more specifically) is only one among many competing or overlapping value systems. They therefore demand and defend the confessional neutrality of the state in order to protect the rights of minorities, atheists, or non-practicing Catholics, and to ensure citizens' equality de jure and de facto. The Catholic Right and the official hierarchy of the Catholic Church, on the other hand, emphasize the "objective" homogeneity of Poland's population, wielding Poland's demographic statistics ("96 percent ethnically Polish, 95 percent Catholic, and 95 percent believers") to bolster claims of monolithic unity and to legally enforce a narrow vision of Poland. Such statistics were used to support and justify the inclusion of an invocatio Dei in the 1997 Constitution (Zubrzycki 2001) and are often invoked to defend the state's policing of social movements that deviate from an imagined national norm. For example, such statistics were thrown around when gay pride parades were banned in Warsaw in the name of 
"public morality." At the occasion of Corpus Christi in 2013, the Archbishop of Kraków, Cardinal Stanisław Dziwisz, gave a new twist to that argument by recognizing that "there exists a plurality of opinions in Poland, [and that] in a democratic society the majority rules." "But," he added, "truth is not determined through voting," which is why "even the parliament cannot create a moral order other than the one deeply inscribed in the heart of man, in his conscience."12 Religious discourse since 1989, then, has been used primarily to constrain individual rights and to shrink the boundaries of Polishness by symbolically excluding those considered "morally unworthy" for full membership_ “Jews," secularists, "bad Catholics," masons (all code names for Jews), and, increasingly, feminists and sexual minorities. ${ }^{13}$

\section{"Magical Antisemitism": Idioms of Nationhood and Logics of Exclusion}

This form of symbolic exclusion points to an interesting paradox. As we know from a rich literature on nationalism (e.g., Brubaker 1992; Schnapper 1994; Yack 1996; Nielsen 1999; Zubrzycki 2001), ideological forms of exclusion are typical of places where the nation is understood in civic terms, and where therefore one's national identity, at least ideally, is determined by his or her adherence to the principles of the social contract, whatever its terms may be. But it ill befits a place where the nation is primarily understood in ethnic terms, following the German, romantic model of nationhood. ${ }^{14}$ In line with this conception, national identity can neither be chosen nor escaped; it is transmitted through birth, "flowing through one's veins," constitutive of an imagined primordial self.

How is it possible, given this latter, dominant understanding of national identity, to exclude ethnic nationals from the nation? How can the conservative Catholic Right insist on the blood-based character of Polishness while simultaneously symbolically excluding some ethnic members on the basis of their beliefs, political opinions, or sexual orientation? How is the tension between these two modes of social closure - one based on blood and culture, the

\footnotetext{
12 At: http://krakow.gazeta.pl/krakow/1,44425,14010318,Kard_Dziwisz_Prawdy_nie_ustala sie przez_glosowanie.html\#ixzz2h3v23Lj0 (accessed 31 May 2013).

${ }^{13}$ On sexual minorities, see Graff's fascinating collection of essays (2008), in which she argues that gays are the "new Jews," and notes the ideological alliance between minority groups toward which the Catholic Right and the Catholic Church are not especially benevolent. This argument has been made more recently by feminist scholar and public intellectual Magdalena Środa in an editorial called "The New Jews." She analyzes the witch-hunt against feminists and the Catholic Church's blaming "gender ideology" for all sorts of social ills, from broken families to pedophile priests; "Nowi Żydzi," Wprost 4 (2014), at: http://www.wprost.pl/ar/432887/Nowi-Zydzi/ (accessed 22 Jan. 2014). On the use of Jewishness and homosexuality as tropes for symbolic exclusion from the national community, see also Mosse 1985, and Bunzl 2004.

${ }^{14}$ The American case is the paradigmatic example of ideologically defined national identity, where "being" American means the support of a specific set of values and practices, and therefore it is possible to be considered "un-American" by some for, say, supporting communism during McCarthyism, or more recently by criticizing the Bush administration after 9-11 or supporting Obamacare.
} 


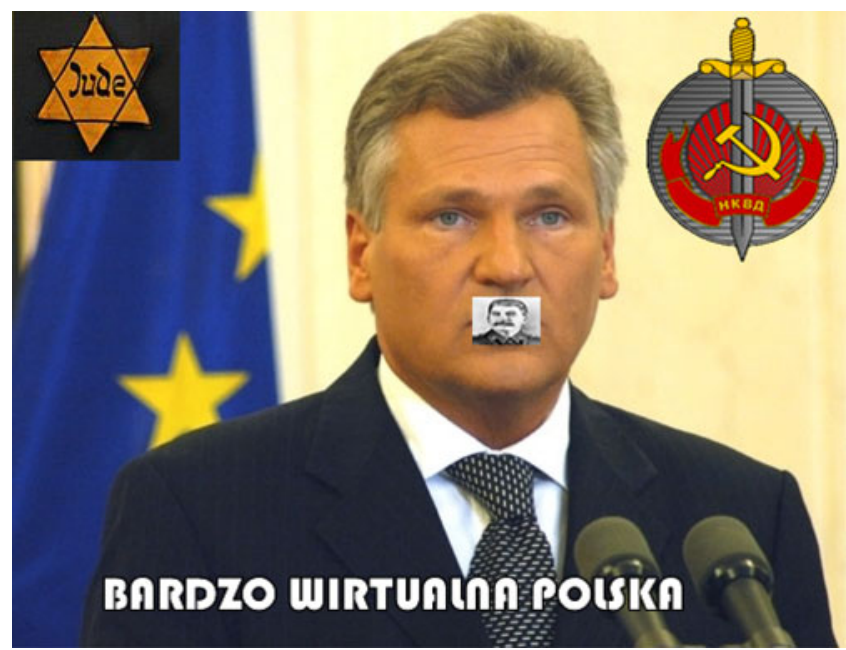

FIGURE 1 From http://bardzo-wirtualna-polska.abceblog.com/ (accessed 4 June 2013).

other on ideological orientations and political bonds-reconciled? In The Crosses of Auschwitz (2006) I showed how "ideological deviance" from the ethno-Catholic definition of Polishness is ethnicized such that individuals and groups that are not defending the prominent place of Catholicism and its symbols in the public sphere, and are advocating instead a civic-secular Poland, are turned into "Jews." This logic and the multiple examples of its application in the public sphere, in both verbal and non-verbal discourse, provide rich exemplars of a phenomenon analyzed long ago by Jean-Paul Sartre (1986 [1946]), who famously claimed that "If the Jew did not exist, the anti-Semite would invent him," or more recently by Enzo Traverso (1997), who explained how one can be Jewish merely by virtue of the Other's gaze. Polish public intellectual Adam Michnik refers to this specific form of antisemitism as "magical antisemitism": "The logic of normal [...] antisemitism is the following: 'Adam Michnik is a Jew, therefore he is a hooligan, a thief, a traitor, a bandit etc.' Magical antisemitism however works this way: 'Adam Michnik is a thief, therefore he is most probably a Jew' (1999: 73)."

But why Jews instead of Ukrainians or Germans, also significant Others in the Polish social imagination? A simple answer to this complex question might be that Communism, Western-style capitalism, and cosmopolitanism are all specifically associated with Jewishness, and that Jewishness is an ethno-religious category that many Poles on the Right perceive as the polar opposite of the Polak-katolik (Krzemiński 1996; 2001). As Jewishness becomes a symbol standing for a liberal, plural, civic, and secular Poland, Poland is said by the conservative Catholic Right to be ruled by "Jews"- by symbolic 


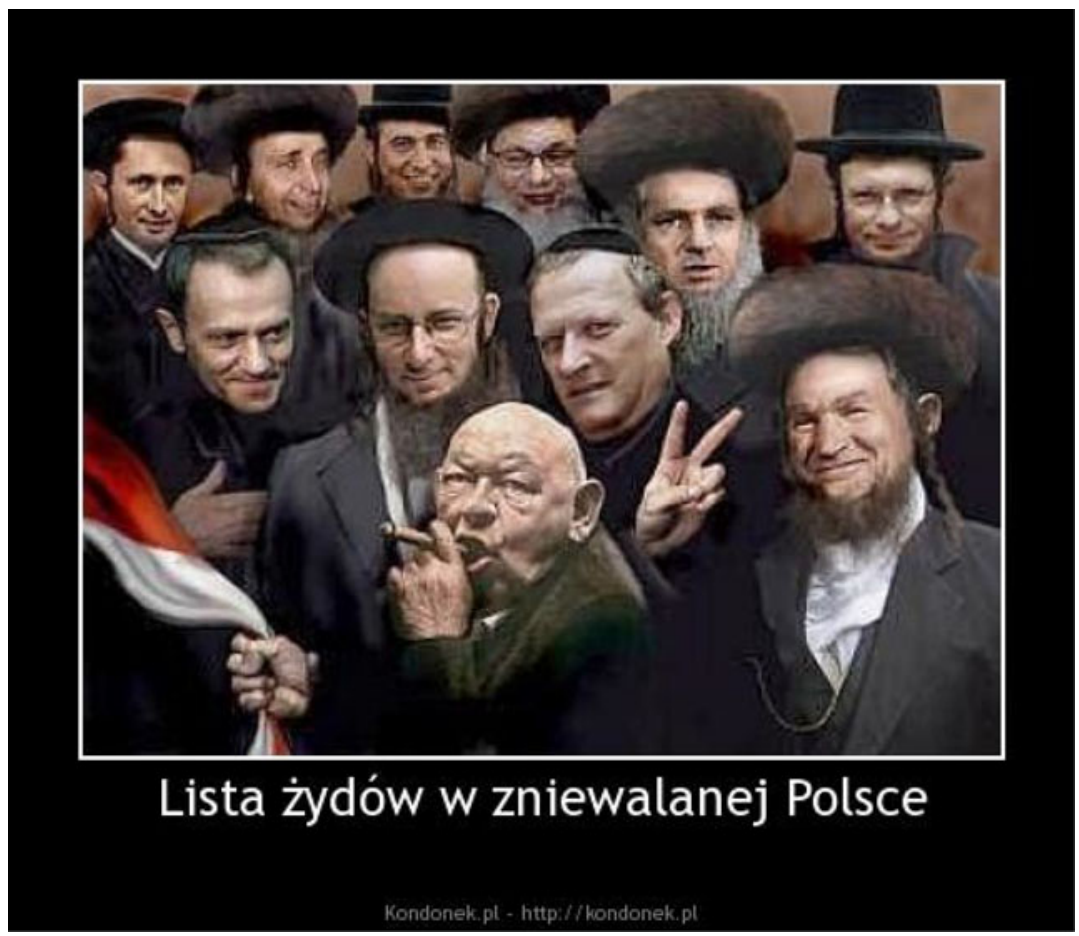

FIGURE 2 From http://bardzo-wirtualna-polska.abceblog.com/wp-content/uploads/sites/10/2013/ 08/zydzi-w-polsce.jpg (accessed 4 June 2013).

Jews - who must be neutralized. Poland is thus host to the apparently curious phenomenon of antisemitism in a country with very few Jews.

Figure 1 captures key components of that type and form of antisemitism. Posted on the Internet, the photo collage is entitled "A very virtual Poland," and depicts former President Aleksander Kwaśniewski (1995-2005) with his mouth taped shut with a photograph of Joseph Stalin. Kwaśniewski, it is implied, is a communist mouthpiece. In the background are a flag of the European Union, which Poland joined in 2004 under Kwaśniewski's leadership, and a Star of David that Jews were forced to wear during World War II. Here, the visual claim is not only that Kwaśniewski is a communist and a Jew-replicating the longstanding trope of żydokomuna, recently analyzed by Paweł Śpiewak (2012) - but that the European Union, too, is a communist/Zionist plot to take over Poland, implied in the juxtaposition of both yellow stars. Finally, on the top right corner, is the insignia of the Soviet NKVD, predecessor of the KGB.

The second figure does not associate symbols of cosmopolitanism, communism, and Judaism to a political formation, but instead visually transforms political elites of various formations, from left to right, into ultra-orthodox 


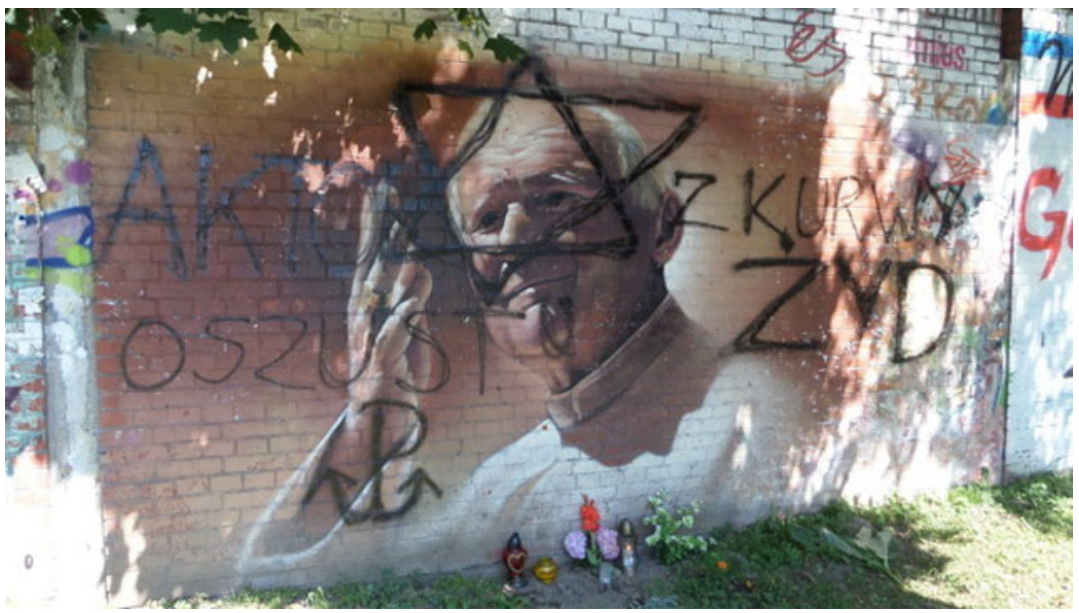

FIgURE 3 Antisemitic graffiti on a mural of Pope John Paul II, in Kraków, summer 2013. It accuses the Pope of being an actor and a fraud, a Jew. ("Z kurwy żyd" is literally "Jew of a bitch" instead of the usual "son of a bitch") because of his ecumenism and rapprochement with "our older brothers in faith.”). Photograph by Marcin Karkosza, used with his permission and that of Gazeta Krakowska.

Jews. ${ }^{15}$ The claim here is that Poland is ruled by Jews, a claim made clear in the caption "List of jews in enslaved Poland." 16 That process of turning opponents into "Jews" is so prevalent that some liberal Catholic Bishops are often accused of being Jewish. Even John Paul II, recently canonized, is not immune to this magical antisemitism (see figure 3).

\section{SOFTENING SYMBOLIC BOUNDARIES}

The very process of ethnicization of deviation from the ethno-Catholic model of Polishness is also at the source of philosemitism. For if ethno-religious nationalists contend that "Jews" are contaminating the nation with their civic ideals, building a pernicious post-national, cosmopolitan world, and must

15 The prominent figure smoking a cigar and unceremoniously holding the Polish flag is Jerzy Urban, former press secretary under communist rule, who made a fortune after the fall of communism with the vulgar, satirical, anti-clerical weekly Nie (No). Such visual depictions of Jews, while absent from mainstream print media, are common on right-wing websites. Magical antisemitism and discourses articulated around żdokomuna are very much present in the Polish public sphere and commonplace in newspapers such as Nasz Dziennik, Gazeta Polska, or the Catholic weekly Niedziela, as well as on the airwaves of Radio Maryja (see note 23).

16 Note here the use of the lowercase ("List of jews"). While in Polish the lowercase is used to denote religious groups ( $\dot{z} y d z i$, katolicy, protestanci, muzutmanie) and capital letters to denote ethnic and national groups ( $\dot{Z} y d z$ i, Polacy, Francuzi), the pervasive use of the lowercase by antisemites even while "grammatically correct" should be understood as an antisemitic typographic practice. 
therefore be politically marginalized, "Jews" must for the same reason be resurrected and Jewishness promoted according to proponents of a civic and secular vision of the polity. Precisely because Jewishness carries specific significations and symbolic capital that other minorities in Poland (such as Ukrainians, Silesians, or the Vietnamese) do not possess, it is primarily through Jews and Jewishness that a modern multicultural Poland is articulated. Hence liberal, leftist youth wear T-shirts and brandish posters in protests against clerical nationalists, subversively claiming that they are "Jews," mocking conspiracy theories of the Right. "I'm a Jew" T-shirts were part of a campaign by the Foundation for Freedom that consisted in "spreading [...] slogans signaling the existence of some taboo topics [...] and discriminated social groups in Poland," including atheists and homosexuals, ${ }^{17}$ while a hip clothing label in Warsaw launched a new "Jewish" line called "Oy." Initially targeted at young Jews, Risk Oy produces relatively pricey T-shirts and hoodies with slogans such as "Thanks to my Mom," adorned with a variety of Star of David designs and Hebrew inscriptions. The owner of the brand told the Times of Israel, "What we really want [...] is to rebrand Jewish identity. We want to show the modern, positive aspects of it. What we are doing is showing that being Jewish is cool and sexy." 18 According to Kraków's JCC director Jonathan Ornstein, there might be no need to "rebrand" Jewish identity, since he has been insisting for years now that "It's hip to be Jewish in today's Poland" (personal communications, Mar. 2011, Mar. 2012, and Mar. 2013). Several non-Jewish volunteers at the JCC and non-Jewish members of a Kraków-based Israeli dance troupe made similar observations, commenting on the fact that "Jewishness is fashionable," one even adding, "...just like in Warsaw it's fashionable to have a gay friend" (interviews, Mar. 2012).

The important question here is why Jewishness (and gayness) is "fashionable" for some non-Jewish Poles. What does it signify for them? The president of the Joint Distribution Committee (JDC) in Warsaw, Karina Sokołowska, specified in the Times of Israel article on Risk's Oy clothing line, "In general, Jews in Poland are looking for ways to express being Jewish, [but the clothing line] is an attractive item for Poland's many philo-Semites" (my emphasis). One such non-Jew quoted in the story, a forty-year-old lawyer living in Warsaw, explained, "Wearing [Risk Oy] is like taking part in a public discussion about Jews in Poland - that Jews live here and that Jews can live here." This is an important comment: that public discussion about Jews in Poland is actually one about the very identity of Poland and a critique

\footnotetext{
17 Other T-shirts part of the 2004 campaign included "I don't go to church," "I don't want to have kids," or "I'm gay." See http://www.tiszertdlawolnosci.tiszert.com/ (accessed 22 July 2012).

$18 \mathrm{http}$ ://www.timesofisrael.com/polish-fashion-entrepreneur-makes-being-jewish-sexy/?utm_source=Newsletter + subscribers\&utm_campaign=0c5a586595-JTA_Daily_Briefing_1 31 2014 \&utm_medium $=$ email\&utm_term $=0 \_-2$ dce5bc6f8-0c5a586595-25416689 (accessed 1 Feb. 2014).
} 
of the still dominant vision of the nation as ethnically Polish and (nominally) Catholic.

\section{Poking Holes in the Catholic Fortress}

Poland is for all because ... no one has the monopoly over her.

Pidżama Porno, punk rock band ${ }^{19}$

It is in the broader context of struggles to define Poland that many non-Jewish Poles' participation in and support for the revival of Jewish culture and communities takes on its full significance. My interviews with key cultural entrepreneurs and numerous non-Jewish activists suggest that their promotion of Jewish culture is part of a broader attempt to expand what it means to be Polish, to counter the Catholic Right's monopoly over the definition of Polishness (Zubrzycki 2013) and to build and promote a plural and secular society in a nation-state with an ethnically and religiously homogenous population. What is intriguing for my purpose here, though, is that many of the same people who argue for a secular society in Poland do not object to the public display of Jewish religious symbols and often even support it. Aneta, a long-time JCC volunteer who is expressly anti-clerical and declares herself an atheist, explained to me during a Shabbat dinner: "I think it's great to see all of that [Jewish religious activity]. I'm not religious but I think it's good to see that there's something else than what we already know, and frankly speaking, we're sick of ... processions, pilgrimages here and there, crosses everywhere...."

Evangelical Christians repeatedly emphasized in our conversations that it was important for them to discover Judaism for theological reasons - "to go back to the source" and "get to know Jesus as a Jew"-but also to support the revival of Jewish communities to build a counterweight to what they see as the all-too-heavy presence of Catholicism in Poland. ${ }^{20}$ Moreover, most practicing Catholics among the JCC volunteers and members of the Israeli dance group I interviewed associated themselves with Catholic movements related to what is called in Poland "open Catholicism," known for being more "intellectual" than ritualistic, close to the liberal Catholic weekly Tygodnik Powszechny, and for actively preaching John Paul II's call for

19 This quote has been used by the non-governmental organization "Poland for All" to promote pluralism: http://polskadlawszystkich.pl/en/pdw_bo (accessed 1 Nov. 2011).

20 Like their American counterparts, Polish Evangelicals see the gathering of Jews in Israel as a prerequisite of the Second Coming of Jesus. But their support of the Jewish revival in Poland proper is also related to the space they want to create for religious minorities like themselves. Moreover, the organizers of the Christian Passover Seder explained to me, teaching and learning about Judaism is a way for Protestants and Catholics to "get together, to speak to each other" (interview, 27 Mar. 2013). 
ecumenism and respect for "our older brothers in faith." 21 This is why the Pope's message and image are often used to counter antisemitism, and also likely one of the reasons why a mural dedicated to his memory in Kraków was vandalized with antisemitic graffiti, in itself a powerful example of magical antisemitism (figures 3 and 4 ). ${ }^{22}$

Some also articulate their support for the revival of Jewish culture partly in opposition to the conservative, reactionary Catholicism of Radio Maryja. ${ }^{23}$ When, at one point in my conversation with another JCC volunteer, Natalia, I mention that the controversial, right-wing Radio Maryja is organizing an anti-government protest in the following days, the middle-aged, well-traveled, polyglot responds: "Argh, I forgot that they still exist.... [But] let's leave these marginals in the margins! Radio Maryja, it's a bunch of old ladies-hopefully they don't have too many young followers. There is a chance, with Jewishness being fashionable, that it means that the young generation is more open [and] that there will be more openness in the future."

Whether Natalia is right about generational change or not, what is significant for our purpose is that the hegemony of Catholicism and the Catholic Church is not combatted via the promotion of other religious communities such as Protestants, Russian Orthodox, Muslims, or Jehovah's Witnesses, who, while small, do exist in Poland, but rather through Judaism and Jewishness more specifically.

21 For a typology of catholicisms within the Polish Catholic landscape, and their specific rapports with Jews and antisemitism, see Zubrzycki 2005.

${ }_{22}$ Tygodnik Powszechny, the most prominent "open" Catholic publication, with which John Paul II was associated before his papacy and which has long worked to increase Polish- and ChristianJewish dialogue, is nicknamed "Żydownik powszechny" by people on the far-right; the word "weekly" (tygodnik) is transformed into "Jewishy" (żdownik). For its sixty-fifth anniversary in 2010, the weekly published a special commemorative issue on Polish-Jewish relations and Christian-Jewish dialogue and changed its name on the first page to Żydownik Powszechny, an astute reversal. Gazeta Wyborcza, Poland's center-left daily founded by Adam Michnik, is also "Jewified" by those on the far-right by being called "Gazeta Koszerna"- the Kosher newspaper, which both implies "Jewish ties and perspectives" but also "politically correct"-uncritical of the Left.

${ }^{23}$ Radio Maryja was established in 1991 as a local station in Toruń. It has quickly expanded into a nation-wide network with an estimated six million listeners. In addition to its radio network and now a television station, Radio Maryja and its charismatic leader, Father Tadeusz Rydzyk, have developed a genuine social movement, with various religious and social organizations, political groups, and publications more or less loosely affiliated with it. "The Catholic voice in your home" exerts a significant influence on the face of Catholicism in Poland by affixing the terms and relative positions that set the boundaries of public debate. Often accused by the Left and by liberal Catholics for having created a sect bordering on heresy, Fr. Rydzyk directs an army of devoted followers, mostly elderly women with few resources other than time, their voices, and their votes to donate to the cause of a "true Poland," a Catholic Poland free of "Jews, Masons, and Satan-loving secularists and communists." Their social, economic, and institutional marginalization fuels their loud involvement in politics. On the discourse of Radio Maryja, see Krzemiński 2009 . 


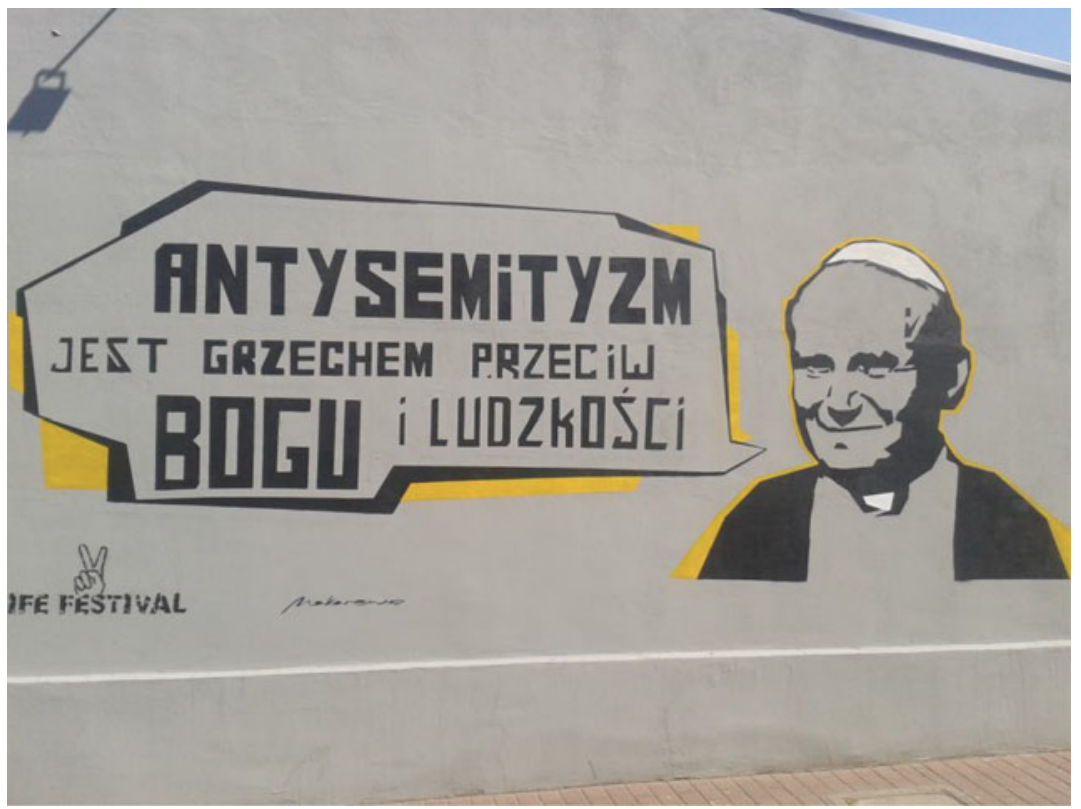

FIGURE 4 On this mural, painted on the occasion of the 2014 Life Festival in Oświęcim (where Auschwitz-Birkenau is located), John Paul II proclaims that "anti-Semitism is a sin against God and humanity.” Photograph by Ted Pearce, Oświęcim, 2014. Used with his permission.

\section{STRETCHING SYMBOLIC BOUNDARIES}

Because in the eyes of ethno-Catholic nationalists only "objective facts" like ethnicity and religious affiliation matter, and since ethnonationality is the dominant, if not hegemonic mode of thinking the nation in Poland, many activists and state agencies create visible, countable, "objective" counterweights. They do so in two main ways: by supporting the institutional growth of Jewish communities and thereby introducing Jewish symbols into the public sphere, and by promoting knowledge about Poland's Jewish past and present through a multitude of cultural events.

\section{Materializing Difference}

As the earlier quote from self-defined atheist Aneta suggests, the presence of Jewish religious life de facto weakens the hegemony of Catholicism, in a way analogous to the way the cross in the public sphere in communist Poland weakened the party-state's claim of monolithic unity. But while the cross in Poland has come to signify a specific vision of the nation and the polity that has become increasingly contested over the past twenty years (Zubrzycki 2006; 2010), the menorah and the star of David have no such 
acquired "baggage" for left-leaning Poles who support a civic and secular vision of the nation. Since the mid-2000s, a giant Hanukiah has been lit in Warsaw on the first night of Hanukkah by Chabad Rabbis, accompanied by city and state officials, and the Chief Rabbi of Poland, Michael Schudrich, lights a Hanukiah at the presidential palace. Both events are photographed and publicized. Such practices cannot be cynically seen as mere electoral strategies by non-Jewish politicians, since the "Jewish vote" is of little significance given the small number of Jews in Poland. But they are certainly addressed as much to international audiences as to national constituencies. The Polish state has been keenly aware of the need to rebrand Poland abroad and there can be little doubt that its support of Jewish-related initiatives is part of that process. ${ }^{24}$ Jewish markers, be they religious or secular, serve to visibly create diversity, thereby somewhat diluting Catholicism's dominance. The mechanism at work here differs from the use of readily available "visible" markers to create boundaries and delimit groups: the goal is rather to stretch existing boundaries by making ideological difference visible, "materialized," and thereby undermining claims of Catholic uniformity. Art and memory projects are an important site for the process of expanding symbolic boundaries.

\section{Social Activism and Memory Work}

Fantasies of the past determined by needs of the present have a direct impact on realities of the future.

Svetlana Boym, The Future of Nostalgia, xvi

The first project I will consider is the much discussed and debated 2007 film Nightmares, made by Israeli visual artist Yael Bartana in collaboration with Sławomir Sierakowski, public intellectual, founder and editor-in-chief of the leftist journal Krytyka polityczna. Nightmares showcases Sierakowski as a political leader standing in the middle of an empty Warsaw stadium overrun by weeds, ${ }^{25}$ shouting a forceful monologue he wrote himself and which, he told me, he "truly, genuinely meant":

Jews! Compatriots! People! [...]

You think the old lady who still sleeps under Rivka's quilt doesn't want to see you? That she has forgotten about you? You're wrong. She dreams about you every night ...

\footnotetext{
24 A prime example is the recent opening of POLIN: Museum of the History of Polish Jews in Warsaw, which the Ministry of Culture advertised and promoted throughout the Western world.

${ }^{25}$ The stadium of the tenth anniversary (stadion dziesięcio-lecia) was built in 1955 to commemorate the end of the Second World War. It was largely constructed with rubble from the Warsaw Uprising of 1944. After 1989 it became Europe's largest open-air market bazaar, where one could buy anything from pantyhose, French perfume, Soviet uniforms, cameras and watches, software and caviar, to exotic spices. It was certainly the most cosmopolitan space per square foot in Poland. It was destroyed in 2008 in preparation of the construction of a new stadium for the 2012 Euro Cup.
} 
and trembles with fear. Since the night you were gone and her mother reached for your quilt, she's had nightmares. ${ }^{26}$ Only you can chase them away. Let the three million Jews that have been missing from Poland return, stand by her bed, and finally chase away the demons. Come back to Poland, to your country!

He goes on to claim, "This is a call not to the dead but to the living":

When you disappeared, we were happy. We said "At last we are home by ourselves. Polish Poles in Poland, no one to bother us." And because we were still unhappy, once in a while we managed to find some Jew to kick out from our country. Even when it was clear that there weren't any of you here, there still were some people who managed to kick you out. And what? Today, it is with boredom that we watch our faces, all similar to each other,... and today we know that we can't live on our own, that we need others, and there aren't others that are closer to us than you. Come live here! We're different but the same! Let's live together! (2013).

Reconnecting with Poland's Jewish past and recognizing the problematic attitude of Poles toward Jews during World War II and its aftermath may be a way to exorcise old demons, but inviting Jews to come back also serves to break the monotony created by an ethnically homogeneous society. While Sierakowski is speaking the words, "it is with boredom that we watch our faces, all similar to each other," Bartana's camera glances over the similar faces of blond scouts who an instant before were busily stenciling on the stadium green, "3,000,000 Jews can change the life of 40,000,000 Poles." Bartana plays with the aesthetics of propaganda films of the 1930s. Nightmares is closest to Leni Riefenstahl's work, especially as Bartana's camera lingers on blond children to comment on the ethnically "pure" Poland that Hitler and Stalin ultimately created. Note also that Sierakowski's dream - to have Jews "return" to Poland to free Poles of their nightmares (war traumas and postwar apocalyptic, mono-ethnic reality) — is actually the Right's nightmare.

The film is a commentary on the nostalgia-infused utopian pluralistic Poland desired by a new Left, while at the same time it knowingly participates in that very political fantasy. The project evolved organically through the close intellectual relationships and friendships developed between Bartana, Sierakowski, and members of Krytyka polityczna (interviews with Sierakowski [2012] and Bartana [2013]). What would happen if three million Jews actually "returned" to Poland? While the first film is about Poland's rapport with Jews, the second and third explore the meaning of Poland for Israel, the implications that a return to Poland by Israelis would have for Palestinians, and the new world that could emerge from that. From a local-national story centered

\footnotetext{
26 Sierakowski refers here to Jewish property that non-Jewish Poles took after their Jewish neighbors were forcibly relocated to ghettos or murdered. There even exists an adjective in Polish to describe property formerly owned by Jews: pożydowskie; literally "from, or after Jews." He also tells the story of a mother taking a blanket from "Rivka" after "she was gone" and under which her child, now an old lady, has been sleeping all her life.
} 
around Polish nightmares and dreams, the complete trilogy (entitled And Europe Will Be Stunned) addresses issues of memory, displacement, and human rights. ${ }^{27}$

Over the years, Bartana and Sierakowski founded a "real" (i.e., non-cinematographic) "Jewish Renaissance Movement in Poland," replete with a manifesto, congresses, delegates, and supporters advocating for the return of Jews to Poland and human rights more broadly. This further blurred the line between art and politics, fiction and reality. The important point for my argument is that building a plural, multicultural Poland in the present is achieved not through the small but existing and visible groups like the Vietnamese, who constitute the largest ethnic minority in Warsaw, or through Silesians, the largest ethnonational minority in Poland, but through Jews- "real, living ones" whom Sierakowski invites to return to Poland, or long-gone ones, like Rivka, who are now missed and remembered. In the trilogy, it is the return of Jews to Poland that renders other minorities visible and relevant. In that discourse, a multicultural Poland is created by, and made possible thanks to, Jews.

\section{Longing and Phantom Limb Pain}

The "missing" and "missed" Jew is at the center of another memory project initiated by performer Rafał Betlejewski. His project, called "I miss you, Jew," endeavors to recover the "true" Poland that has been lost with the disappearance of Jews from the national landscape. In a series of graffiti works and happenings throughout Poland, Betlejewski writes, with the active participation of local populations, "I miss you, Jew. I miss you in Poland, in all these little villages and big cities. You left a [void] there. Both in space and my heart. I just wanted you to know that. Polak" (http:/www.tesknie.com/index.php?id=50). The graffiti was often painted in spaces formerly occupied by Jewish individuals, families, or communities to memorialize their lives. Groups of memory activists pose, for example, in Poznań's former synagogue, "repurposed" as a swimming pool by the Nazis in 1940 (figure 5); by a store; in a train station; in the woods. Betlejewski would also photograph himself and others in various sites next to an empty chair, signifying the missing - and missedJew, and post the pictures on a dedicated website/memory book. At the bottom of the main webpage, in Polish, is a banner stating, "For Poles, the synonym for the word zagłada [genocide] should be the word 'loss"" (http:// www.tesknie.com/index.php?id=32).

27 And Europe Will Be Stunned was selected by the Polish ministry of Culture to represent Poland at Venice's Biennale in 2011. Bartana was the first non-Pole to represent Poland at such a prestigious event. For an insightful analysis of the project and discussion of other artistic, performative, and participatory memory works in contemporary Poland, see Lehrer and Waligórska 2013. 


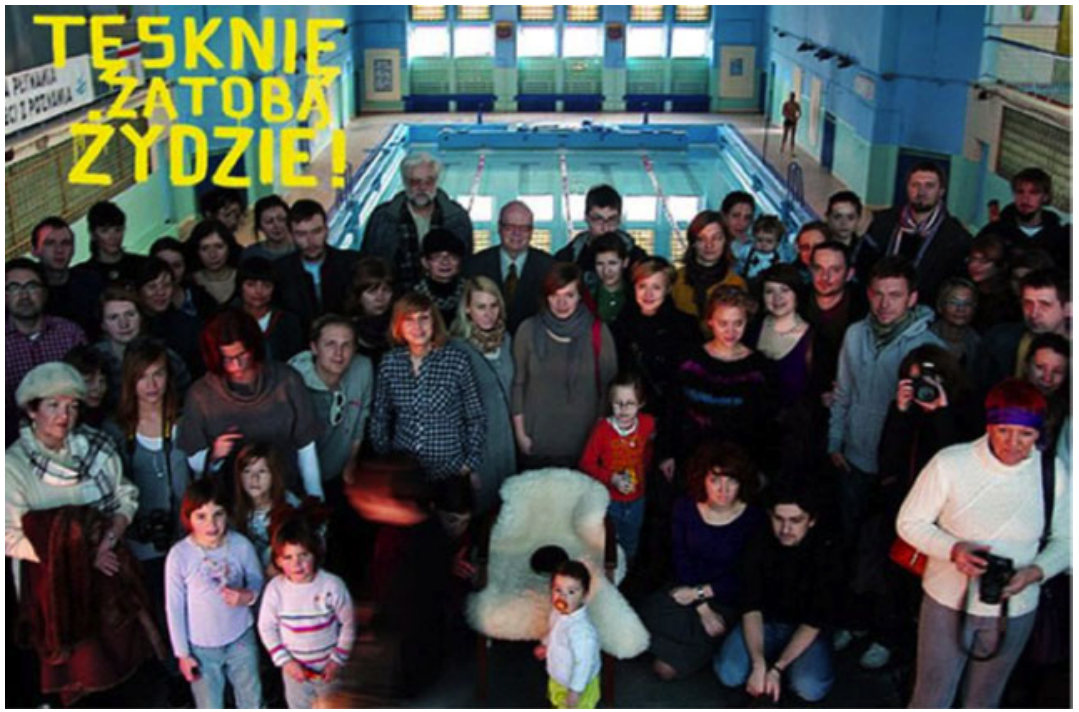

Figure 5 "I miss you, Jew" happening in the Poznań New Synagogue, built in 1907 and repurposed as a swimming pool for Wehrmacht soldiers by the Nazis in 1940. Recently it was converted into a gallery space, and plans to establish a Center for Judaism and Dialogue are under discussion. Source: () Rafał Betlejewski, used with permission of the artist.

Combatting antisemitism by purging the word "Jew" of its negative connotations in Polish is just one of this project's aims; ${ }^{28}$ it also works to reclaim the memory of a part of Poland and Polish national identity that is experienced much like a phantom limb pain. ${ }^{29}$ That is, the tragic "disappearance" of Jews and Jewish culture from Poland is presented (and increasingly experienced) in many Polish milieu as a tragic loss for Polish culture, and it is in that name that it must be rescued, saved, revived.

The website also provided a venue where Poles could post remembrances - their own, their parents', or their grandparents' - of specific Jewish individuals or vanished Jewish communities. Here are two evocative examples of the sort of testimonies that appear there:

28 The name of the project, "I miss you, Jew," has been controversial, since it was initially interpreted as antisemitic graffiti, for which Betlejewski was arrested until he explained the meaning of the expression. This is telling in two ways: first, it shows a much greater sensitivity to antisemitism than in years prior and demonstrates the authorities' prompt responses to what is interpreted as antisemitic gestures. But most significantly, that the slogan "I miss you, Jew" painted on a wall was immediately interpreted as an antisemitic gesture suggests the extent to which the word "Jew" is a bad word in Polish. See my in-depth analysis of this memory project (2013).

${ }^{29}$ For such pain to be felt, however, knowledge about the prior existence of the limb must exist. It is the postwar generations' realization of that past existence that I describe elsewhere as a "narrative shock" (2006; 2013). 
I miss you, Jew! I live in western Wielkopolska. Today I'm twenty-one years old and I deeply regret that I was not given the opportunity to know the entire history of my town. In the very center of Wolsztyn stood a beautiful synagogue, just by the square. Today there is no trace of it. I want to retell the history that my great-grandfather told my grandmother, and which she then told me. During the war my family had a big farm. The entire day was spent working in the field, especially during the summer time. That field was next to a forest. One day, some Jew who was hiding in the woods came to ask my greatgrandfather (...) for food. They agreed. I remember how my grandma described the fear, even if this was a village.... They left food in the woods, between trees, and that Jew, I don't know his name or age, took the food and hid himself underground. This didn't last too long, probably a few months. One day the food was left untouched. Same thing the following morning. I don't know what happened to that Jew but I hope that he survived! Jew, I miss you! I would very much like some day to talk with him, ask how he managed, help him find his roots. I very much regret that there are no Jews left in Wolsztyn. It is a huge loss. I'm also sorry that in 2009 someone burned the synagogue. We still don't know who did it. I only hope that someday I'll see a smiling Jew who will be walking the streets of my town and be part of it, like it used to be (Aleksander, at http://www.tesknie.com/index.php?id=1416).

So little and yet so much was left after them. The history of Łęczna Jews is just as incredible as it is forgotten. But I remember. And I long (Bajka, at http://www.tesknie. com/index.php?id=1408).

The second example is a brief yet eloquent commentary on history, memory, and longing, but without details or story. The first testimony, on the other hand, relates a specific incident lived by the author's grandparents, part of familial memory (and perhaps mythology). It is an earnest narrative with typical details and holes, and the author's hopeful but naïve idea of what a Poland with Jews was and would be like. Svetlana Boym defines nostalgia "as a longing for a home that no longer exists or has never existed" (2001: xiii). It is that home that many Poles are looking for. But nostalgia is also "a romance with one's own fantasy" (ibid.), which Aleksander's testimony exemplifies: "his" memory ends matter-of-factly with a passing comment on a recently torched synagogue, but without any critical reflection on what the relationship could be between the past event he recalls, his own nostalgia, and the antisemitism that endures. Jewish absence facilitates the nightmares of the Right and their negative stereotypes of Jews, but also the dreams of the Left. The Jewish body is an empty container, filled with Polish aversions, fears, desires, and aspirations.

RESHAPING SYMBOLIC BOUNDARIES

Poland is for all because ... it has always been for all. For centuries, Poland prospered because of its multi-ethnic and multi-religious population. It culturally and spiritually enriched Poland in the past and we can only pray that it will continue to do so in the future. Michael Schudrich, Chief Rabbi of Poland ${ }^{30}$

\footnotetext{
30 Quote used by the non-governmental organization "Poland for All" to promote pluralism: http://polskadlawszystkich.pl/en/pdw_bo (accessed 1 Nov. 2011).
} 
The multiple festivals of Jewish culture in the four corners of Poland seek to educate Poles (and tourists) about the culture of Jews who once lived in Poland and contributed to Polish culture. The claim is not merely about mutual influence: rather, Jewish culture is constitutive of Polish culture. Polish culture, these activists claim, is not only about Catholic practices and folklore. It is about broad universalist values that have shaped a long tradition of "religious tolerance" and "civic openness" that led to the flourishing of Jewish religious and communal life, prosperous Jewish towns and peaceful shtetls, and Polish culture. As Janusz Makuch, the co-founder and director of Kraków's Festival of Jewish Culture, told me in one of our conversations:

Whether people know it or not, it is a fact that Jews, for many, many centuries,... made tremendous contributions to Polish culture. So when we're talking about Polish culture, we're equally taking about Jewish culture. Without the contribution of Jews, true Polish culture couldn't exist. Forget it! Literature, architecture, sculptures, historians, intellectuals, music, economics, politics, food. So everything was intertwined and still is, thank God. What I'm trying to do ... is to help Poles realize what is theirs (1 Mar. 2012, original conversation in English).

The recognition of the Jewish past and the presence of cultural markers in contemporary Poland therefore allow public figures, teachers, and activists to plausibly argue for a civic definition of Polishness. Because in the postwar period the communist regime coopted (and corrupted) civic discourse, that vision of the national community is often perceived as "foreign." Today's civic nationalists must work harder to create a plausible and desirable civic project. To render that vision of the nation legitimate and "truly Polish," they reach into the distant past and re-narrativize Polish history to emphasize ethnic and religious diversity, political openness and tolerance, and political freedom. They point to the large number of Jews who settled in Poland as evidence of the historical roots of a Polish civic nation. Poland's historical religious tolerance also allows them to articulate a discourse that sets Poland apart from other European nations. As I heard so many times in various venues, "When Jews were being kicked out from Southern and Western Europe, King Kazimierz the Great was welcoming them in Poland." That narrative of Polish exceptionalism is significant, and I will return to some of its implications, but here I want to emphasize the link that cultural entrepreneurs, public intellectuals, artists, and ordinary citizens make between Jews and Poland's Europeanness. For Mirka, a woman in her early twenties who had been volunteering at the JCC for two years when I met her, the presence of Jews in Poland would allow Poles to feel more at ease in the new Europe: "I'm totally for Jews living here, as it was before, as it was before the war. Then it would be more comfortable for us in Europe because we'd be more open, more understanding toward differences in general." At one point in Bartana's Nightmares, Sierakowski implores Jews to return so that "we shall finally be European." 
The promotion of Jewishness in festivals, memory projects, and many other institutional projects are also thought to be bringing Poland back to her "true essence." In the words of Makuch, "Kraków was always a multicultural place, where cultural pluralism was often very obvious. However this national monotheism, religious monotheism, that was created after the Second World War is scorching me, hurting me. I really don't like this-so let's go back here to what is the basis of our spirituality, actually, since Jews were Polish citizens" (interview, 19 Mar. 2011). That discourse has been perfectly integrated by various groups involved in the Jewish revival. Ania, a woman in her late twenties who dances in the Israeli dance group as a hobby and is a practicing Catholic, explained to me that she wants to learn about Jews and Jewish culture to better know herself as a Pole:

Well, basically, there has been a Jewish presence in our country ( $u$ nas) for eight hundred years, on our lands, here in Poland, so there is this influence that we don't remember anymore because there are almost no Jews left in Poland. There are very few. [But it's important to know that culture] so that we can better know ourselves. Our identity, who we are, what we have - ... we owe [it] not only to ourselves, but also to other communities who lived here. And Jews lived here in great numbers. So we owe them for their contributions in the academic and scientific sphere where there were a lot of Jews, and in the administration here in Kraków. There were Jewish mayors, many well-known lawyers at Jagiellonian University, many architects, in music too. So they contributed a lot. In literature too! They were a big influence. Not long ago I was talking with friends about hospitality, how Poland and Poles are known for their hospitality (kind of), but that hospitality actually comes from Jewish culture!"

In this discourse and related practices, modernity, Europeanness, and multiculturalism, as well as cultural forms and national traits, are achieved through and thanks to Jews.

In another key passage of his speech in Bartana's Nightmares, Sierakowski deplores that with "one color, one cannot see." To properly see, one needs more colors, and for many Poles Jews bring that metaphorical color. The posters advertising Kraków's Festival of Jewish Culture in the past two decades provide a rich visual demonstration (figure 6). The use of color is certainly meant to connote the life and vibrant culture of Jews rather than the greyness and stark black and white photographs associated with the Holocaust (exemplified in Schindler's List). However the consistent use of rainbow colors is also meant to convey the diversity that Jews represent and bring to Poland (interview with Janusz Makuch, 1 Mar. 2012). That visual scheme has been extended and used by multiple organizations fighting antisemitism and promoting Jewish culture and multiculturalism. Jews, whether in the past or the present, "real" or "symbolic," allow Poles to build a multicolored, pluralist Poland against the mono-ethnic white and red, and the black shirts of neo-fascist groups. 


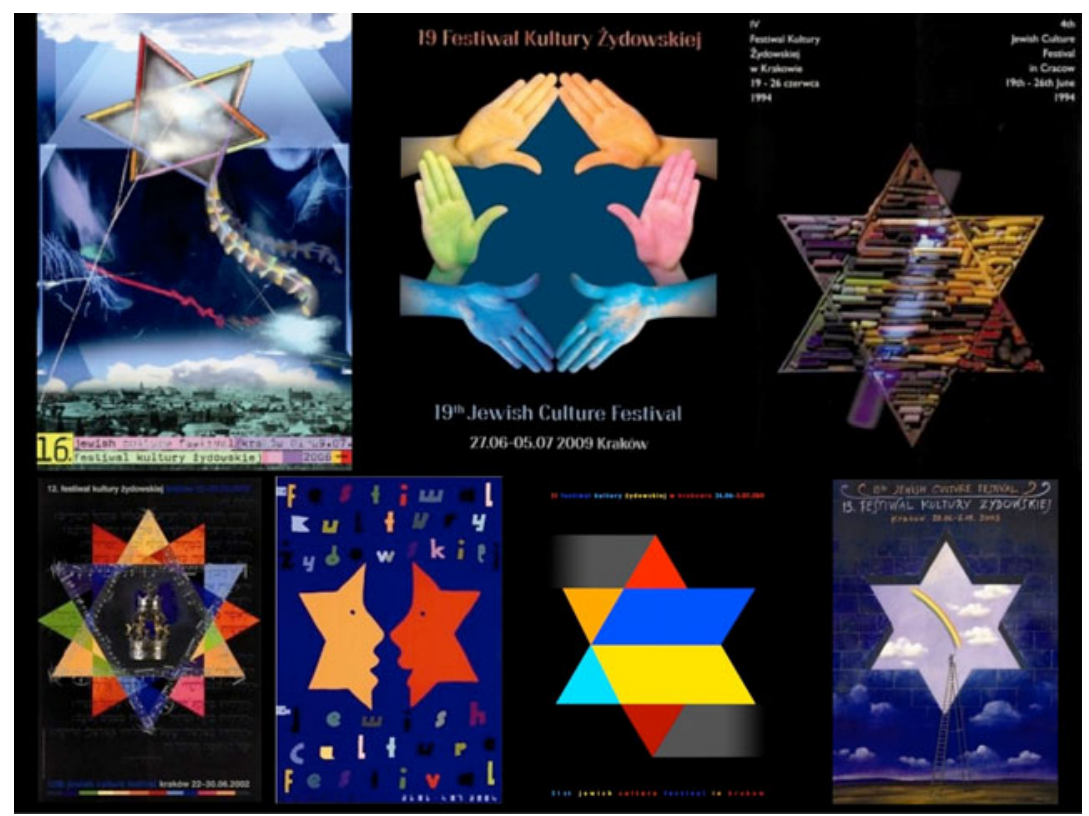

Figure 6 Posters from Kraków's Festival of Jewish Culture, 1994, 2002, 2003, 2004, 2006, and 2009. Source: (C) Jewish Culture Festival Society, jewishfestival.pl.

\section{"Our Jews": Otherness and Indigeneity}

There aren't Others that are closer to us than you....

We're different but the same! Let's live together!"

Sierakowski, Nightmares

This still begs the question: why do those who wish to build pluralism focus on Jews instead of Silesians or Vietnamese? One explanation that I have already provided is that Jewishness carries a specific signification and symbolic capital: modernity, cosmopolitanism, urbanity. Another is that Jews are basically absent from the Polish landscape and are therefore both non-threatening and available to be filled with one's fantasies: nightmares or dreams depending on one's political orientation. Yet another reason is that Jewishness, unlike Ukrainian-ness, Silesian-ness, or Vietnamese-ness, is at once exotic and somewhat "indigenous." It is different enough, yet as Kasia told me in a conversation in 2012, it "was nourished from the Polish soil and grew on these lands." Ola, a Lutheran from Silesia who majored in Judaic studies and art history and is now a museum educator in a Catholic institution, explained: "On one hand, [Jewish culture] is, let's say, 'oriental.' But on the other hand, because it developed in Poland, in spite of everything it's somehow very much tied with Poland, yes? 
It's kind of an exotic element in our environment. It's not something like ... Swahili somewhere far off in Africa, but [rather] something that is different from Polish culture yet at the same time related to it, inseparable even." It is that duality - exoticism and familiarity - that according to another JCC volunteer makes Jewishness so appealing for non-Jewish Poles: "We could talk about [Jewish culture] as a foreign culture, different from Polish culture if we wanted ... to separate, but we are still aware that we're talking about a culture that was here for centuries. But it's still something exotic, right? And yet, totally close to us. So it's easy to become interested in [Jews and Jewish culture] and become fascinated. It becomes fashionable."

Jewishness is thus both "Other" and "Ours," an observation made spontaneously by countless other interviewees. As another young woman who volunteers at the JCC told me, "Jewish culture is 'exotica' right here at home." It is the ideal indigenous Other. In that discourse, to revive Jewish culture allows Poles to become "authentically" multicultural. It allows the recovery of a truer national self and the reshaping of symbolic boundaries of the nation through the Other. This is an Other whose extermination was grossly silenced for half a century, leaving a mnemonic void that a new generation of Poles is eager to uncover and discover to become more authentically Polish. Embracing pluralism and Jewishness is not only part of branding Poland as modern and European; it is also giving Poland back her "true" shape.

\section{CONCLUSION}

The extermination of Jews and destruction of Jewish culture in Poland is presented, and increasingly experienced, in liberal intellectual, artistic, and ecumenical milieu as a tragic loss for Polish culture and identity, and this is why it must be rescued, saved, or even resurrected. Poland, individuals in those groups argue, is not homogeneous. But instead of emphasizing the ideological heterogeneity of its current population as a legitimate form of diversity, they emphasize its (ethno)cultural heterogeneity, the result of an ethnically and religiously diverse past. By creating "objective," tangible, visible, countable - and growing-Jewish Others, a new generation of social actors and cultural agents implicitly and often explicitly contest the claim of the nation's ethnic and religious homogeneity. Symbolic boundaries in contemporary Poland are thus being redefined by overlapping discursive and performative practices: they are softened by poking holes in the ethno-Catholic fortress, stretched through memory work, and reshaped by discursively naturalizing and "indigenizing" Jewishness as "Polish."

This is not to say that Catholicism's hegemonic place in Poland is only or even primarily contested and countered via the support of Judaism and Jewish culture. It is also operated via movements of religious exit (such as apostasies), formal demands for a stricter separation of church and state, and support of the rights of various alternative groups, primarily sexual minorities and feminists 
who, significantly enough, also support the revival of Jewish communal life since they understand their minority status and struggle as being shared by Jews. Nor am I denying that the "revival" is also about other important projects and processes, for it obviously is. What I have argued in this article is that there exists an elective affinity between non-Jewish Poles' support of, and participation in, the revival of Jewish culture and preservation of Jewish memory and their desire to build a Poland that is different from the one forcefully promoted by the Catholic Church and the Right. Resurrecting Jewish culture and actively supporting Jewish communities' revival of Judaism gives concrete shape to seemingly amorphous ideological pluralism in order to trump the "hard" demographic "facts" of Poland's ethno-religious homogeneity, ${ }^{31}$ and as a way to neutralize Catholicism as a religious tradition with political traction.

These discursive and performative strategies do not whitewash history to erase traces of antisemitism. For many of my interviewees, "revelations" of violent crimes committed against Jews by ethnic Poles (e.g., Gross 2000; 2006; Gross and Grudzińska-Gross 2011) sparked their initial interest in Jewish history and culture. Likewise for consciousness-raising efforts such as Betlejewski's "I miss you, Jew" project. He explained to me in 2011 that learning about the 1941 murders of Jews in Jedwabne was a "life-changing event" for him as a person and as a Pole. Nor are these discursive and performative strategies purely instrumental: I am not asserting that the people involved are not genuinely interested in Jewish culture or Judaism, or that they do not care about the memory of those murdered in the Holocaust. But in their artistic creations, beliefs, discourses, and actions, and alongside and through their cultural investments in Judaism, they weave their individual identities and private life-projects into a vision of Poland that is severed from that presented by Polonia semper fidelis.

By showing the varied processes through which ethnic, religious, and ideological identifications are constructed in everyday life in the present, managed through discursive recourse to the past, expanded through institutional affiliations, and legitimated by government programs and agencies, this case study makes the following contributions to the literature on nationalism and cultural sociology more broadly:

First, it shows us how a symbolic category - here Jewishness - can serve as a foil to construct not only an exclusive ethnic nation, but also to build an inclusive, civic, and secular nation. I have shown that in Poland the national self is being built not only against the Other (the Jew), but also through that indigenous Other in opposition to an alleged primordial "self"- the ethno-Catholic Pole. This is more than the simplistic story of philosemitism

\footnotetext{
31 Note that the civic vision also essentializes the national community. What is seen to be the "true" and "natural" Poland, however, is not the ethnically and denominationally homogeneous nation, but rather its past multi-ethnic and multi-denominational version.
} 
opposing antisemitism —or "anti-antisemitism." Rather, Polish philosemitism is part of a larger process of redefining national identity. Jewish culture is but one thread woven into the dense tapestry of the civic national counter-narrative, yet it is an especially important motif given both the long history of Jews on Polish lands and the trauma of their eradication from the national landscape. It is also important because it helps the state to rebrand Poland on the international scene, a motivation that cannot be ignored.

The Polish case shows just how complex the process of national redefinition can be, since in order to expand the definition of Polishness, difference must be introduced and legitimated. And that difference implies the maintenance of symbolic boundaries. As Eviatar Zerubavel has powerfully shown, "In order to focus on anything, we must perceive some discontinuity between that which we attend and that which we ignore.... It is boundaries ... that allow us - visually as well as mentally - to grasp any entity at all" (1991: 118-19). While it is by including Jews in the national narrative and conception of a new national self that the symbolic boundaries of Polish national identity are stretched and reshaped, it is so precisely because Jews are "different," "Other." The inclusion of Jews within the symbolic perimeter of the nation in order to redefine Polishness does not, and cannot, de-Otherize the Jew. The Jew must irremediably remain Other. The study thus highlights the tension that is intrinsic to expanding the symbolic boundaries of the nation through the Other, because that Other, whether real or symbolic, remains malleable at the hands of those who control the category. The symbolic power exerted to "articulate the principles of vision and division" for a particular group, to quote Bourdieu (1991), is thus still "violent" even when it is used in progressive projects meant to expand the symbolic boundaries of the group.

Secondly, this study shows how what Brubaker (1992) has called "idioms of nationhood" - cultural schemes or ways of conceiving one's nation - shape not only formal rules of membership (i.e., citizenship), but also the logic of symbolic membership. That the nation is generally imagined in ethnic terms in Poland (and in the region more broadly) explains why certain members are symbolically excluded from the national community for their political ideas or values by being "ethnicized," by being turned into ethnonational Others. It also explains why proponents of a civic vision of the nation cannot rely on its abstract principles to sell that project and must resort to recreating Jewish culture as "real," as a visible counterweight to the ethno-religious national community. Paradoxically, then, ethnicity remains the prism through which social actors attempt to transcend ethnonationalism. My point is that one has to pay attention to dominant idioms of nationhood to understand not only formal political modes of inclusion or exclusion via citizenship, but also the logic of symbolic inclusion and exclusion in nationalist discourse and practices. 
That observation also helps us to understand other cases. Consider France, the archetype of civic nationhood, where inclusion into the national community is premised not on blood but upon one's adherence to the social contract. How can the French Right legitimately exclude threatening ethnic and racial others? It does so by ideologizing them, by turning Arabs and Africans into dangerous Muslims who threaten the Republic by infringing upon secularism, a sacred tenet of the social contract.

Third, this work contributes to the scholarship on nationalism and everyday life which has shown that the construction of national identity is a process that operates not only at the level of elite discourse and institutional (re)arrangements, through official policies or state-sponsored institutions such as museums, educational programs, or NGO outreach actions, but also through memory work, cultural initiatives, and everyday practices undertaken by multiple actors in a variety of venues (Billig 1995; Brubaker et al. 2006; Fox and Miller-Idriss 2008). What I have shown here is that these practices do not serve to reproduce an existing national identity but to de- and re-construct identity along new lines. Polishness is being challenged and redefined by activists and artists as well as by ordinary people in their mundane activities. Multiple forms of memory work such as graffiti art, walking tours of formerly Jewish spaces, commemorative marches, or the cleaning and restoration of cemeteries all serve to undermine the political claim and the dominant view that Poland is essentially, primordially ethno-Catholic. Ordinary Poles become involved in the revival and assimilate Jewishness, to the extent that it becomes "Polish," through embodied and repeated actions-by learning how to "cook Jewish" or how to serve and consume Jewish foods during a festival, at a café all year round, or at a Sabbath dinner at the JCC; by singing and dancing; by learning Jewish paper-cutting techniques; or by donating their time and energy to Jewish individuals and organizations.

Finally, this study contributes to the literature on symbolic boundaries by showing the intricate processes through which the line separating the national self from the Other is negotiated and redrawn on the ground. I have identified three main, diachronic, and overlapping processes at play in the redefinition of national identity: softening, stretching, and reshaping. I showed that in order to expand the notion of what a given national identity "is," dominant visions must be undermined. In the Polish case, that softening process is primarily achieved discursively, through critiques of the Catholic Church. Symbolic boundaries are stretched by making the contemporary Jewish presence visible and by materializing traces of the Jewish past. The stretched boundaries of Polishness are reshaped and legitimated by Poles participating in cultural work that indigenizes the Jew and Jewish culture, thereby naturalizing an alternative model to the dominant one that links Polishness to Catholicism. In that narrative, it is the pluralistic Poland that is the "true" Poland, while postwar Poland is a casualty of the Nazis and Communists, taken hostage by the Catholic Church. 


\section{REFERENCES}

\section{Formal Interviews (Public Figures)}

Bartana, Yael (visual artist, director of the film trilogy And Europe Will Be Stunned, cofounder of the Jewish Renaissance Movement in Poland). 2013. Audio-recording, Berlin, 17 Jan.

Betlejewski, Rafał (performing artist, initiator of "I miss you, Jew."). 2011. Audio-recording, Warsaw, 24 Mar.

Herberger, Tyson (Rabbi in Warsaw, 2010-2013, Wrocław 2013-2015). 2012. Warsaw, 27 Sept.

Horovitz, Itzchak (Rabbi and Kraków’s Mashgiah). 2012. Audio-recording, Kraków, 29 Feb.

Makuch, Janusz (co-founder and director of Kraków's Festival of Jewish Culture). Audio-recordings, Kraków. 2011 (19 Mar.), 2012 (1 Mar.), and 2013 (27 Mar.)

Ornstein, Jonathan (director, Jewish Community Center). Audio-recordings, Kraków. 2011 (Mar.), 2012 (Mar.), and 2013 (Mar.).

Pash, Boaz (rabbi). 2012. Audio-recording, Kraków, 6 Mar.

Schudrich, Michael (chief rabbi of Poland). 2012. Audio-recording, Warsaw, 28 Sept. Segal, Tanya (rabbi, Beit Kraków). 2012. Audio-recording, Kraków, 7 Mar.

Sierakowski, Sławomir (public intellectual, founder of Krytyka Polityczna, author and actor in Yael Bartana's film trilogy And Europe Will Be Stunned, co-founder of the Jewish Renaissance Movement in Poland). 2012. Audio-recording, Warsaw, 26 Sept.

\section{Primary and Secondary Sources}

Alteflix, Thomas. 2000. The 'Post-Holocaust Jew' and the Instrumentalization of Philosemitism. Patterns of Prejudice 34, 2: 41-56.

American Jewish Yearbooks, 1989, 2002, 2003.

Bauman, Zygmunt. 1998. Allosemitism: Premodern, Modern, Postmodern. In B. Cheyette and L. Marcus, eds., Modernity, Culture, and 'the Jew.' Cambridge: Polity Press, 143-56.

Bilewicz, Michał, Mikołaj Winiewski, and Zuzanna Radzik. 2012. Antisemitism in Poland: Economic, Religious, and Historical Aspects. Journal for the Study of Antisemitism 4: 2801-20.

Billig, Michael. 1995. Banal Nationalism. London: Sage.

Blobaum, Robert, ed. 2005. Antisemitism and Its Opponents in Modern Poland. Ithaca: Cornell University Press.

Bourdieu, Pierre. 1991. Language and Symbolic Power. Cambridge: Harvard University Press.

Boym, Svetlana. 2001. The Future of Nostalgia. New York: Basic Books.

Brubaker, Rogers. 1992. Citizenship and Nationhood in France and Germany. Cambridge: Harvard University Press.

Brubaker, Rogers, Margit Feischmidt, Jon Fox, and Linnea Grancea. 2006. Nationalist Politics and Everyday Ethnicity in a Transylvanian Town. Princeton: Princeton University Press.

Bunzl, Matti. 2004. Symptoms of Modernity: Jews and Queers in Late-TwentiethCentury Vienna. Berkeley: University of California Press.

Cała, Alina. 1995. The Image of the Jew in Polish Folk Culture. Jerusalem: Magnes Press.

Casanova, José. 1994. Public Religions in the Modern World. Chicago: University of Chicago Press. 
Centrum Badania Opinii Społecznej. 2009. Wiara i religijność Polaków 20 lat po rozpoczęciu przemian ustrojowych. Warsaw: CBOS.

Centrum Badania Opinii Społecznej. 2013. Osoby niewierzace w Polsce: Kim sa oraz jakie uznaja normy $i$ wartości? Warsaw: CBOS.

Chomątowska, Beata. 2012. Stacja Muranów. Sękowa: Wyd. Czarne.

Dodziuk, Anna. 2010. Druga dusza: O dwudziestu latach Kultury Żydowskiej w Krakowie. Warsaw: Wydawnictwo Czarna Owca.

Forecki, Piotr. 2010. Od Shoah do Strachu: Spory o polsko-żydowska przeszłość i pamięć $w$ debatach publicznych. Poznań: Wydawnictwo Poznańskie.

Fox, Jon E. and Cynthia Miller-Idriss. 2008. Everyday Nationhood. Ethnicities 8, 4: 536-63.

Gebert, Konstanty. 2008. Living in the Land of Ashes. Kraków: Austeria Publishing House.

Gitelman, Zvi. 2003. Collective Memory and Contemporary Polish-Jewish Relations. In Joshua D. Zimmerman, ed., Contested Memories: Poles and Jews during the Holocaust and Its Aftermath. New Brunswick: Rutgers University Press, 271-90.

Grabowski, Jan. 2013. Hunt for the Jews: Betrayal and Murder in German-Occupied Poland. Bloomington: Indiana University Press.

Graff, Agnieszka. 2008. Rykoszetem. Rzecz o ptci, seksualności i narodzie. Warsaw: W.A.B.

Gross, Jan T. 2000. Sąsiedzi. Sejny: Pogranicze.

Gross, Jan T. 2006. Fear: Anti-Semitism in Poland after the Holocaust. New York: Random House.

Gross, Jan T. and Irena Grudzińska-Gross. 2011. Złote żniwa. Kraków: Znak.

Gruber, Ruth Ellen. 2002. Virtually Jewish: Reinventing Jewish Culture in Europe. Los Angeles: University of California Press.

Irwin-Zarecka, Iwona. 1989. Neutralizing Memory: The Jew in Contemporary Poland. New Brunswick: Transaction Publishers.

Janicka, Elżbieta. 2011. Festung Warschau. Warsaw: wyd. Krytyki Politycznej.

Jochnowitz, Eve. 1998. Flavors of Memory: Jewish Food as Culinary Tourism in Poland. Southern Folklore Quarterly 55, 3: 224-37.

Judaken, Jonathan. 2008. Between Philosemitism and Antisemitism: The Frankfurt School's Anti-Antisemitism. In Phillys Lassner and Lara Trubovitz, eds., Antisemitism and Philosemitism in the Twentieth and Twenty-First Centuries: Representing Jews, Jewishness and Modern Culture. Newark: University of Delaware Press, $23-46$.

Karp, Jonathan and Adam Sutcliff, eds. 2011. Philosemitism in History. New York: Cambridge University Press.

Krajewski, Stanisław. 2005. Poland and the Jews: Reflections of a Polish Jew. Kraków: Austeria.

Kraków Festival of Jewish Culture (FKŻK). Annual Reports, 1991-2013.

Krzemiński, Ireneusz, ed. 1996. Czy Polacy sa antysemitami? Wyniki badania sondazowego. Warsaw: Oficyna Naukowa.

Krzemiński, Ireneusz. 2001. Polacy i Żydzi: wizja wzajemnych stosunków, tożsamość narodowa i antysemityzm. In Aleksandra Kania, ed., Trudne sąsiedztwa. $Z$ socjologii konfliktów narodowościowych. Warsaw: Wydwanictwo narodowe Scholar, 171-200.

Krzemiński, Ireneusz, ed. 2009. Czego nas uczy Radio Maryja? Warsaw: WAiP.

Kugelmass, Jack and Anna-Maria Orla-Bukowska. 1998. If You Build It They Will Come: Recreating a Jewish District in Post-Communist Kraków. City and Society Annual Review, 315-53. 
Lamont, Michèle and Virag Molnar. 2002. The Study of Boundaries in the Social Sciences. Annual Review of Sociology 28: 167-95.

Lehrer, Erica. 2003. Repopulating Jewish Poland - in Wood. Polin: Studies in Polish Jewry 16: 335-55.

Lehrer, Erica. 2013. Jewish Poland Revisited: Heritage Tourism in Unquiet Places. Bloomington: Indiana University Press.

Lehrer, Erica and Magdalena Waligórska. 2013. Cur(at)ing History: New Genre Art Interventions and the Polish-Jewish Past. East European Politics and Societies and Cultures 27, 3: 510-44.

Machcewicz, Paweł and K. Persak. 2002. Wokót Jedwabnego, Volume 1, Studia. Warsaw: Instytut Pamięci Narodowej.

Meng, Michael. 2012. Shattered Spaces: Encountering Jewish Ruins in Postwar Germany and Poland. Cambridge: Harvard University Press.

Michlic, Joanna B. 2006. Poland's Threatening Other: The Image of the Jew from 1880 to the Present. Lincoln: University of Nebraska Press.

Michnik, Adam. 1999. Wystąpienie. In B. Oppenheim, ed., Kościót polski wobec antysemityzmu, 1989-1999: Rachunek sumienia. Kraków: WAM, 69-76.

Michowicz, Waldemar. 1988. Problemy mniejszości narodowych. In J. Tomicki, ed., Polska Odrodzona, 1918-1939. Warsaw: Wiedza Powszechna, 285-321.

Mosse, George L. 1985. Nationalism and Sexuality: Respectability and Abnormal Sexuality in Modern Europe. New York: Fertig.

Murzyn, Monika. 2006. Kazimierz: The Central European Experience of Urban Regeneration. Kraków: International Cultural Centre.

Mushkat, Marion. 1992. Philo-Semitic and Anti-Jewish Attitudes in Post-Holocaust Poland. Lewiston: Edwin Mellon Press.

Nielsen, Kai. 1999. Cultural Nationalism, neither Ethnic nor Civic. The Philosophical Forum: A Quarterly 28, 1-2: 42-52.

Ostachowicz, Igor. 2012. Noc żywych Żydów. Warsaw: Wyd. WAB.

Penn, Shana, Konstanty Gebert, and Anna Goldstein, eds. 2009. The Fall of the Wall and the Rebirth of Jewish Life in Poland: 1989-2009. Warsaw: The Taube Foundation.

Polonsky, Antony. 2009. Polish-Jewish Relations since 1984. Kraków: Austeria.

Porter-Szücs, Brian. 2012. Faith and Fatherland: Catholicism, Modernity, and Poland. New York: Oxford University Press.

Reszke, Katka. 2013. Return of the Jew: Identity Narratives of the Third Post-Holocaust Generations of Jews in Poland. Brighton, Mass.: Academic Studies Press.

Sartre, Jean-Paul. 1986 [1946]. Anti-Semite and Jew. New York: Schocken Books.

Schnapper, Dominique. 1994. Sur l'idée moderne de la nation: La communauté des citoyens. Paris: Gallimard.

Śpiewak, Paweł. 2012. Żydokomuna. Warsaw: Czerwone i Czarne.

Steinlauf, Michael. 1997. Bondage to the Dead: Poland and the Memory of the Holocaust. New York: Syracuse University Press.

Stern, Frank. 1991. The Whitewashing of the Yellow Badge: Antisemitism and Philosemitism in Postwar Germany. New York: Pergamon.

Tokarska-Bakir, Joanna. 2008. Legendy o krwi: Antropologia przesadu. Warsaw: W.A.B.

Tomaszewski, Jerzy. 1993. The National Question in Poland in the Twentieth Century. In M. Teich and R. Porter, eds., The National Question in Europe in Historical Context. Cambridge: Cambridge University Press, 293-316.

Traverso, Enzo. 1997. L'Histoire déchirée: Essai sur Auschwitz et les intellectuels. Paris: Ed. Cerf.

Tuszyńska, Agata. 2005. Rodzinna historia lęku. Kraków: Wydawnictwo Literackie. 
Waligórska, Magdalena. 2008. Fiddler as a Fig Leaf: The Politicization of Klezmer in Poland. In Manfred Sapper, ed., Impulses for Europe: Tradition and Modernity in East European Jewry. Berlin: Osteuropa, 227-38.

Waligórska, Magdalena. 2013. Klezmer's Afterlife: An Ethnography of the Jewish Music Revival in Poland and Germany. New York: Oxford University Press.

Wodziński, Marcin. 2011. Jewish Studies in Poland. Journal of Modern Jewish Studies 10, 1: 101-18.

Yack, Bernard. 1996. The Myth of the Civic Nation. Critical Review 10, 2: 193-211.

Zerubavel, Eviatar. 1991. The Fine Line: Making Distinctions in Everyday Life. New York: The Free Press.

Zubrzycki, Geneviève. 2001. "We, the Polish Nation": Ethnic and Civic Visions of Nationhood in Post-Communist Constitutional Debates. Theory and Society 30, 5: 629-69.

Zubrzycki, Geneviève. 2005. 'Poles-Catholics' and 'Symbolic Jews': Jewishness as Social Closure in Poland. Studies in Contemporary Jewry 21: 65-87.

Zubrzycki, Geneviève. 2006. The Crosses of Auschwitz: Nationalism and Religion in Post-Communist Poland. Chicago: University of Chicago Press.

Zubrzycki, Geneviève. 2010. What Is Pluralism in a 'Monocultural' Society? Considerations from Post-Communist Poland. In Courtney Bender and Pamela Klassen, eds., After Pluralism: Re-Imagining Models of Interreligious Engagement. New York: Columbia University Press, 277-95.

Zubrzycki, Geneviève. 2013. Narrative Shock and (Re)Making Polish Memory in the Twenty-First Century. In Florence Vatan and Marc Silberman, eds., Memory and Postwar Memorials: Confronting the Violence of the Past. New York: Palgrave, 95-115.

\begin{abstract}
This article analyzes the growing interest in Jews and all things Jewish in contemporary Poland - from the spectacular popularity of festivals of Jewish culture to the opening of Judaica bookstores and Jewish cuisine restaurants; from the development of Jewish studies programs at various universities and the creation of several museums to artists' and public intellectuals' engagements with Poland's Jewish past and Polish-Jewish relations more broadly. Drawing on ethnographic fieldwork, over sixty formal interviews with Jewish and non-Jewish activists, and informal conversations with participants in various Jewish-centered initiatives, I argue that this cultural phenomenon is related to the attempt by specific political and social groups to build a pluralistic society in an ethnically and denominationally homogenous nation-state. I build on the literature on nationalism and symbolic boundaries by showing that bringing back Jewish culture and "resurrecting the Jew" is a way to soften, stretch, and reshape the symbolic boundaries of the nation that the Right wants to harden and shrink using Catholicism as its main tool.
\end{abstract}

